\title{
A PLANTA BAIXA DE DOM CASMURRO DOM CASMURRO'S GROUND-PLAN
}

\author{
Audemaro Taranto Goulart*
}

RESUMO: Este texto pretende ler o romance Dom Casmurro, de Machado de Assis, considerando o capítulo IX como a planta baixa da obra. Examinando-se detidamente o capítulo IX, é possível deduzir que ele ocupa uma posição estranha e deslocada na narrativa, uma vez que ele não se insere na seqüência dos fatos. Por isso, acredita-se que ele tem uma função especial na obra, surgindo como um resumo da história, um plano onde personagens e acontecimentos estão esquematizados, anunciando o que acontecerá em toda a trama. PALAVRAS-CHAVE: Dom Casmurro, Machado de Assis, romance brasileiro, leitura crítica.

ABSTRACT: This text aims at reading Machado de Assis's novel Dom Casmurro, considering chapter IX as the ground-plan of the work. If chapter IX is examined accurately, it is possible to deduce its strange and displaced position in the narrative for it's not the sequence of facts at all. Because of this one believe it has a special function in the work, appearing as a resume of the story, a plan where characters and situations are schematized, announcing what will happen all over the plot. KEY WORDS: Dom Casmurro, Machado de Assis, brazilian novel, critical reading.

* Pontifícia Universidade Católica de Minas Gerais, Belo Horizonte. Doutor em Letras (Teoria Literária e Literatura Comparada). Email: ataranto@ pucminas.br. 



\section{A PLANTA BAIXA DE DOM CASMURRO}

\section{Proposição}

Pode-se dizer que nenhum livro levantou tanto interesse na literatura brasileira quanto o Dom Casmurro. A obra vem, ao longo de seus cento e poucos anos de vida, seduzindo e instigando leitores. Essa dimensão chegou, nos dias de hoje, ao seu ponto máximo, como mostra a onipresente polêmica sobre o adultério de Capitu que está mais acesa que nunca, embora uma parte da crítica insista em dizer que ela não tem importância e que não é a parte essencial do livro.

Essa perspectiva tem gerado discussões inflamadas. De um lado, há os que negam a possibilidade de se confirmar a traição pelo simples fato de que ela não aparece na narrativa e também porque o informante da história é Bentinho, parte interessada na questão. De outro, há os que não duvidam de que Bento Santiago foi traído, e dentre eles alinham-se leitores respeitáveis como Otto Lara Resende, escritor festejado, que usou seu espaço de cronista na Folha de São Paulo para, mais de uma vez, afirmar sua certeza de que o adultério realmente aconteceu.

Também Carlos Heitor Cony, outro escritor festejado, que, inclusive, substituiu Otto na Folha, usou o mesmo espaço para levantar em duas crônicas uma séria suspeita: o adultério ocorrera, de fato, na vida do próprio Machado que, assim, não teria feito mais que recriar, literariamente, um lance autobiográfico. Para tanto, Cony vai a uma crônica de Humberto de 
Campos, onde se insinua que Mário de Alencar, filho do escritor José de Alencar, era, na verdade, filho de Machado com Georgiana Cochrane.

Outro que merece ser citado é o jurista José Paulo Sepúlveda Pertence, ministro do Supremo Tribunal Federal. Sua participação deu-se como presidente de um júri idealizado pela Folha de São Paulo, em 1999, como um dos eventos que marcaram as comemorações do centenário de Dom Casmurro. Na circunstância, um júri não faria outra coisa senão julgar Capitu, o que foi realizado com toda pompa e estilo. Basta dizer que o advogado de acusação foi ninguém menos que Márcio Thomaz Bastos, ex-presidente da OAB e ex-ministro da justiça do governo Lula, enquanto na defesa de Capitu atuou a advogada Luíza Nagib Eluf, atuante no Foro paulista. Mas o que vale mesmo é o registro da fala de Sepúlveda Pertence, depois de absolver Capitu: "Não sei, se devesse votar secretamente num júri, se resistiria à minha convicção íntima moral de que existiu o adultério. Mas devo agir aqui como juiz profissional, impedido de decidir por consciência e obrigado a decidir conforme as provas".

Para finalizar, e voltando ao grupo de escritores consagrados, cito Fernando Sabino que publicou, em 1998 um livro pretensioso, o Amor de Capitu, chamado por ele de recriação literária e que tinha como proposta fazer uma leitura do Dom Casmurro sem o narrador Bentinho, no pressuposto de que a narração em terceira pessoa poderia lançar luz nova sobre o que Sabino chama de "mistério a mais" da narrativa. Tal mistério seria decorrência de o narrador fazer digressões, citações e comentários diversos que acabam mascarando o relato. Mas o que me interessa aqui é destacar a convicção do escritor mineiro quanto à figura de Capitu. Diz ele, com todas as letras, que "não foi a intrigante e todavia óbvia infidelidade da personagem principal" que mais o motivou na sua recriação mas sim "até que ponto a dúvida teria sido premeditada pelo autor, através de um narrador evasivo, inseguro, ingênuo, preconceituoso e casmurro, como o apelido que assumiu para si mesmo" (1998, p. 8).

Como se vê, o livro de Machado de Assis se faz de tal modo sedutor que é impossível lê-lo sem que a voz das personagens deixe de ciciar alguma coisa nos ouvidos do leitor. Desse modo, seja aquela leitura ingênua, em que o leitor se preocupa apenas em perguntar "e depois, o que aconteceu?", seja na leitura fina, em que se discutem aspectos sutis que procuram flagrar a psicologia da composição da narrativa, o leitor estará irremediavelmente enredado nas malhas de Dom Casmurro. E a sedução chega ao ponto de levar intelectuais, críticos, professores e escritores a reproporem novas modalidades de leitura, representadas por livros como o citado Amor de Capi- 
$t u$, de Fernando Sabino, e outros que aproveitam o filão do texto machadiano, trabalhando também a perspectiva da recriação, como é o caso de experiências recentes de Domício Proença Filho que escreveu o seu Capitu - Memórias Póstumas, e a parceria do professor Flávio Aguiar com a atriz Ariclê Perez, autores da peça Criador e Criatura, que fala de um presumível encontro de Capitu com o escritor ${ }^{1}$.

Tais experiências parecem ser o limite mesmo das tentativas de penetrar o texto de Machado, na expectativa de que nele há reentrâncias inexploradas e, por isso mesmo, propícias para desvelar o seu enigma desafiador. Elas vêm se somar à já copiosa relação de teses, ensaios, artigos, conferências e comunicações que Dom Casmurro tem suscitado ao longo de sua existência² ${ }^{2}$.

${ }^{1}$ Outras produções recentes que relêem a obra de Machado são: Por onde andará Machado de Assis?, romance-ensaio de Ayrton Albuquerque (Nankin/Edusp) e Memorial de Buenos Aires, romance de Antônio Fernando Borges (Companhia das Letras).

${ }^{2}$ Seria ocioso citar tudo quanto se publicou sobre Dom Casmurro. Limito-me, aqui, a elencar alguns dos principais trabalhos aparecidos na forma de livros que focalizam, exclusivamente, o romance de Machado de Assis, alguns deles já tidos como clássicos: The brazilian Othello of Machado de Assis, de Helen Caldwell (Berkeley, University of Califórnia Press, 1960); O enigma de Capitu, de Eugênio Gomes (Rio de Janeiro, José Olympio, 1967); A metáfora do mar no Dom Casmurro, de Linhares Filho (Rio de Janeiro, Edições Tempo Brasileiro, 1978); Plenitude perdida, de Donaldo Schüler (Porto Alegre, Editora Movimento/Instituto Estadual do Livro, 1978; Duas meninas, de Roberto Schwarz (São Paulo, Companhia das Letras, 1997). Acho necessário citar ainda, a edição de Dom Casmurro preparada pela Comissão Machado de Assis, publicada pelo Instituto Nacional do Livro, em 1969. A importância dessa edição está no fato de ela trazer apontamentos notáveis, como uma cronologia bibliográfica e uma bibliografia em que se indicam as edições, traduções e os estudos referentes ao romance, aparecidos até aquela época. Mas o principal dela está no fato de trazer, como apêndice, o texto "Um agregado", que Machado de Assis publicou no jornal República, em 1896, e que foi por ele chamado de "capítulo de um livro inédito". Na verdade, o livro inédito era o Dom Casmurro e o tal capítulo nada mais que uma redação primitiva dos capítulos III, IV e V do romance que sairia três anos depois. Acho imprescindível também fazer referência à Revista Scripta, n. ${ }^{\circ} 6,1^{\circ}$ semestre de 2000, publicação do Programa de Pós-graduação em Letras e do Centro de Estudos Luso-afro-brasileiro da PUC Minas, uma edição dedicada a Machado de Assis. Dela, destaco três ensaios: "Dom Casmurro começou na imprensa por José Dias", de Letícia Malard, um trabalho instigante que toma exatamente "Um agregado" e disseca o texto, confrontando-o com a edição definitiva, de Dom Casmurro, e, por isso, chegando a conclusões muito interessantes; "Estratégias de embuste: relações intertextuais em Dom Casmurro", de Marta de Senna, em que a ensaísta mostra como o narrador do romance tece suas artimanhas para incriminar Capitu e "Palavra, olhar e silêncio em Dom Casmurro", de Erick Ramalho de Souza Lima, um texto inovador no que diz respeito à leitura que se propõe não para o que está dito mas para o que se silencia na narrativa machadiana. 
De minha parte, proponho mais uma leitura do romance machadiano, na convicção de que ela possa servir, quando nada, como mecanismo que colabore para a fruição da narrativa. Quero, pois, lançar um olhar curioso sobre o capítulo IX, uma vez que, no meu entendimento, ali está o que chamo de planta baixa do livro.

\section{Um pouco de teoria: traços, percepções e sintomatologia dos discursos}

Sempre defendi o princípio de que os traços identificadores da gênese de uma obra ficam impressos nela mesma. São inúmeras as passagens teóricas que podem vir em abono dessa afirmação. Se tomo, por exemplo, o desconstrucionismo de Derrida, vejo que ele se apóia num princípio que compreende a busca de marcas que se fazem presentes no texto. Assim, para Derrida, desconstruir é uma "operação que consiste em denunciar num determinado texto (o da filosofia ocidental) aquilo que é valorizado e em nome de quê e, ao mesmo tempo, em desrecalcar o que foi estruturalmente dissimulado nesse texto". (1976, p. 17).

Com essa presunção, Derrida quer contestar a filosofia ocidental, principalmente no que apresentam as obras de Husserl e Descartes. Já aí se produz uma desconstrução: a crença de que existe uma distinção entre sujeito e objeto. Com ela, põe-se em xeque a afirmação de que a consciência, por sua própria natureza, está em contato com uma realidade externa a ela, caracterizando o pressuposto de que existe uma realidade polarizada em um "dentro" (a consciência) e um "fora" (o mundo externo), com o privilégio concedido à consciência. Para Derrida, essa crença da metafísica ocidental está centrada num logos - o eídos, a verdade -, preocupada em valorizar um significado que traduz essa verdade. Daí as hierarquizações que privilegiam, por exemplo, o dentro, o inteligível, a palavra, a essência, a verdade e a presença, em detrimento de seus opostos.

Ora, diante dessas determinações da filosofia ocidental, é de se supor que a intenção dos autores que produzem na órbita dessa filosofia deixa-se impregnar pelas influências dela decorrentes. A anuência - consciente ou não - do produtor de textos a certas convenções lingüísticas e literárias faz com que os significados resultantes dessa interação encubram significados mais profundos que, por terem sido recalcados, não se oferecem à leitura superficial.

Não é por outro motivo que Derrida, ao trabalhar a desconstrução de um texto, pense nos traços que existem nele. Tais traços tanto podem 
aparecer como algo residualmente presente para a observação quanto podem configurar-se nos próprios signos lingüísticos. O importante dessa noção é que os traços caracterizam-se como alguma coisa que está presente para o sujeito, mas que está também marcado na função de sua ausência. Isso significa que o traço deve ser tomado como um processo, de vez que é através de sua posição dinâmica que se promove a operação de desconstrução do texto. Dessa forma, a análise do material lingüístico deve considerar os referentes conscientemente pretendidos pelo autor, para submetêlos a um processo de desestruturação de forma que possam emergir desse material os subtextos que serão investigados, a fim de que a autenticidade referencial oculta no texto assim como seu conteúdo inconsciente tornem-se visíveis.

Em outros termos, pode-se dizer que, para Derrida, a operação de leitura deve considerar o texto no seu interior - o que ele diz -, para, em seguida, lê-lo de fora, examinando o que ele recalcou ou dissimulou, isto é, suas metáforas. Esse conteúdo inconsciente - o que foi reprimido, os significados que não puderam ser expressos conscientemente -, é que se determina como algo referencialmente autêntico e é composto, em boa parte, de material ideológico.

Para operar essa análise, Derrida propõe decodificar a sintomatologia dos subtextos através do auxílio de narrativas-mestras, como as de Freud, Marx e Nietzsche. É com o auxílio desses textos que se torna possível "desmanchar" o discurso cristalizado pela força do logocentrismo da metafísica ocidental, fazendo aparecer aquilo que foi camuflado ou suprimido, consciente ou inconscientemente pelo autor.

Desse modo, nessa perspectiva derridiana, detectar e apontar o que foi reprimido é trabalho que se identifica com a busca de traços a que venho me referindo.

Mas há outras instâncias em que a investigação no texto pode levar à determinação de marcas importantes impressas no seu material lingüístico. Uma delas é o acionamento dos mecanismos da psicanálise, campo em que, a começar por Freud, pontifica um grande número de estudiosos e pesquisadores. Dentre eles, quero destacar Anton Ehrenzweig, psicanalista que tem uma obra especificamente voltada para a investigação dos elementos inconscientes que atuam na elaboração da obra artística. Nesse contexto, destaca-se um livro especialmente importante para este meu ensaio. Tratase do Psicanálise da percepção artística - Um introdução à teoria da percepção 
inconsciente, em que o pesquisador alemão confere ênfase especial às chamadas formas inarticuladas no trabalho da criação artística.

Nesse sentido, Ehrenzweig chama a atenção para o fato de que nossa percepção de superfície tem uma tendência à articulação, ou seja, quase sempre tendemos a perceber as formas precisas, simples e compactas, em detrimento de outras que poderiam ser identificadas como indefinidas, incoerentes e inarticuladas. É por isso que, segundo o autor, a chamada psicologia da Gestalt presta muita atenção à forma articulada (Gestalt) ${ }^{3}$, passando ao largo dos elementos inarticulados que se excluem desse processo formatador. Para fazer frente a essa lacuna, inúmeros psicólogos/psicanalistas dedicaram-se a estudos que visam, sobretudo, ao exame de tais formas inarticuladas, com o que nasceu o que se chama de psicologia da percepção profunda, de que Ehrenzweig é um dos expoentes.

Em termos muito sumários - já que, aqui, quero apenas apresentar mais um mecanismo que ajude a esclarecer a questão dos traços do texto -, poder-se-ia dizer que as percepções do sujeito dão-se através da mente de superfície e da mente profunda.

As investigações que se realizam nesse terreno têm insistido na concepção de que, no nível de um psiquismo profundo, processam-se elementos inarticulados que não estão ao alcance da mente de superfície e que, por isso mesmo, ainda não foram por ela formatados, ou seja, não passaram pelo processo da Gestalt. Justamente pelo fato de a mente de superfície perceber apenas as formas articuladas é que, durante muito tempo, incidiu-se no equívoco de equipararem-se as formas inarticuladas, na sua estruturação original, com as interrupções do fluxo de consciência, como se tais formas fossem apenas um intervalo, um descontínuo, ocorrente na percepção dos elementos conscientes.

Freud mostrou, muito explicitamente, a existência de elementos inconscientes que se manifestam através dessas formas inarticuladas que seriam, assim, verdadeiros mensageiros do inconsciente. É importante, ainda, ressaltar que a dificuldade que existe para a aceitação desses elementos inarticulados é a mesma que, de um modo geral, se tem para aceitar o papel da grande influência que o inconsciente desempenha na vida das pessoas. É por esse motivo que a psicanálise ensina como o inconsciente é atuante. Basta ver como se configura o mecanismo do sonho, por exemplo, para perceber-se como

\footnotetext{
${ }^{3}$ Gestalt (do alemão): forma, conformação, aspecto.
} 
elementos que, à primeira vista, parecem ser casuais ou dispersos podem estar, na verdade, encobrindo um importante conteúdo inconsciente que, certamente, tem influência decisiva no equilíbrio emocional da pessoa.

É importante ainda lembrar os mecanismos que processam o ato criador. Segundo Ehrenzweig, a ação criativa da mente humana provoca uma paralisação temporária das funções de superfície, a fim de que as funções profundas, arcaicas ou menos diferenciadas, possam operar. Vai ocorrer, então, um estágio transitivo que consiste em fazer com que as formas existentes nesse nível sejam rearticuladas, de modo a serem traduzidas em estruturas mais diferenciadas, o que possibilita à mente de superfície uma melhor compreensão delas. É nessa dimensão que se pode compreender o trabalho do artista, ou seja, compete a ele buscar o que seria sua visão inspiradora, em que estariam as formas inarticuladas, para moldá-las em formas articuladas, ou seja, para traduzi-las em imagens que possam ser apreendidas através de uma codificação, de uma linguagem.

Esse trabalho de tradução dos elementos inarticulados é realizado através da Gestalt, isto é, a mente de superfície impõe seus mecanismos de formatação de modo a tornar as formas claras e precisas. Tal processamento, entretanto, desfigura a originalidade das formas inarticuladas. Todas aquelas sensações ligadas aos mecanismos do prazer e do gozo, que são proporcionados por experiências arcaicas depositadas nas profundezas da mente, acabam se perdendo pelo fato mesmo de ser impossível a sua transformação perfeita num código, numa linguagem. De tais percepções da mente profunda restam, no fim do processo de transição, apenas alguns vestígios, sinais que se dão pouco à observação. Como se vê, estou falando de traços e eles, na verdade, aparecem num texto, muitas vezes, como defeitos, cochilos ou descuidos do autor, enfim eles se mostram como desvios do discurso organizado. Encontrá-los não será difícil. Basta que se tenha a acuidade de uma observação atenta.

Ehrenzweig ilustra bem essa condição desviante do discurso escrito, utilizando o exemplo da pintura. Assim, ele chama a atenção para o fato de que, na pintura moderna, tem-se um claro desvio da teoria gestaltista, uma vez que, de um modo geral, tal pintura faz o olho "divagar". Para o autor, uma comparação entre um quadro de pintor moderno e o de um pintor tradicional mostra muito claramente que, neste último, existe uma definição de formas que atrai de imediato a atenção do observador para determinados aspectos que são ressaltados, uma vez que o artista tem uma clara intenção do que deseja expressar. 
Para Ehrenzweig, essa estrutura pregnante ${ }^{4}$ e simples da pintura tradicional confirma os ensinamentos da teoria gestaltista, segundo a qual toda percepção ou criação de formas está sujeita a uma tendência que leva a perceber ou produzir uma estrutura tão pregnante e simples quanto possível. O olho, como órgão sensorial, apenas registra um desordenado e caótico mosaico de pontos; o cérebro projeta uma configuração definida nesse caos que percebemos como formas e contornos ao nosso redor.

"Mesmo que as formas que nos cercam sejam realmente caóticas, ainda assim o cérebro projeta nelas uma ordem. De uma miscelânea de pontos, o olho (ou, para ser mais exato, o cérebro) escolhe aqueles que se enquadram em alguma estrutura, ou os que poderiam ser interpretados como uma forma humana ou animal". (1977, p. 63-4).

No caso da pintura moderna, entretanto, tudo se dá de modo diferente uma vez que, não havendo um núcleo da composição que centralize a atenção, as formas acabam por ser ambíguas, justamente porque elas nada têm que possa fixar a acuidade visual do espectador. Assim, as formas da pintura moderna adotam a técnica de "repelir o olho", conforme observa Ehrenzweig, pois elas se apresentam, normalmente, superpostas e não justapostas, considerando-se aí o fato de que as partes de uma estrutura para se encaixarem numa Gestalt têm de estar justapostas.

Ehrenzweig exemplifica o que foi dito com uma pintura de Picasso. "Em um quadro de Picasso encontramos um violão superposto a um membro do corpo humano; se prestarmos atenção ao violão e ao membro separadamente, cada um desses elementos vai nos remeter a um outro conjunto adjacente de formas que se justapõe a eles respectivamente. Na medida em que o olho desliza sobre as formas superpostas e coincidentes, a estrutura completa do quadro parece se deslocar continuamente como se cada parte do todo levasse a uma nova justaposição de formas. Qualquer tentativa de uma análise das formas precisas, como é possível na pintura tradicional, falharia e deixaria nossos olhos embaçados e tensos". (1977, p. 67).

Aproximando-se essas considerações da leitura de um texto, pode-se dizer que a fuga intencional da Gestalt é uma forma de ativar a chamada técnica da percepção difusa. Nesse sentido, é preciso compreender que a atenção,

\footnotetext{
${ }^{4}$ De acordo com o tradutor do livro de Ehrenzweig, "no texto em inglês lê-se pregnant, vindo do alemão prägnaz cujo significado é conciso. Em português pregnante é usado em Psicologia (especialmente na Psicologia da Gestalt), para adjetivar uma percepção tão "boa" quanto possível” (p. 63).
} 
no ato de ler, deve voltar-se para o todo do texto e não apenas para aquelas partes que se oferecem com nitidez à leitura. Não há dúvida de que resolver um problema no jogo de xadrez ou em qualquer outro que exija a acuidade da combinação de elementos produz um prazer estético semelhante ao que se experimenta na relação com um objeto estético. Assim, valorizar aqueles traços que aparentemente não têm importância ou parecem produtos de lapsos e deslizes do escritor é, na verdade, tomar contato com elementos que brotam do inconsciente e que estão muito próximos da originalidade das formas inarticuladas que sustentam a criação do texto, ou seja, formas reveladoras de estruturas que se estabelecem no universo da pura estesia, do prazer já experimentado. A leitura que consegue descobrir a funcionalidade semântica desses traços há de ser, necessariamente, uma leitura prazerosa.

Continuemos, pois, com a busca dos traços no romance de Machado de Assis.

\section{Traçado e traços da narrativa: a ópera}

É com esses cuidados que quero convidar o leitor a ler o Dom Casmurro, ou seja, quero lembrar que é preciso estar atento a tudo quanto pareça estranho ou diferente na narrativa. Aqui, acho necessária uma observação importante: como se viu na parte anterior, na maioria das vezes, o estranho é decorrência de investimentos de elementos inconscientes, mas também pode ser uma estratégia do próprio autor. No caso de Machado de Assis, é bem provável que o estranho em seus textos seja, predominantemente, resultado de suas "bruxarias"5.

Iniciemos, pois, com algumas considerações introdutórias.

Começa-se a leitura e lá vem o primeiro capítulo, "Do título", em que o narrador explica o título do livro, a partir da alcunha - Dom Casmurro - que lhe puseram.

Depois vem o capítulo II, "Do livro", em se revelam as intenções do narrador na composição da história: "O meu fim evidente era atar as duas pontas da vida, e restaurar na velhice a adolescência”.

No capítulo III, "A denúncia", tem início a história propriamente dita e é quando Bentinho percebe a preocupação do agregado, José Dias, em lembrar a sua mãe, D. Glória, a necessidade de metê-lo, o quanto antes, no seminário.

\footnotetext{
${ }^{5}$ A propósito, convido o leitor a buscar os ensaios de Letícia Malard e de Marta de Senna, citados na nota 2 .
} 
No capítulo IV, "Um dever amaríssimo", a história mal tem seqüência, uma vez que José Dias dá apenas alguns passos para o interior da casa, ocupando-se o resto do capítulo com a grotesca descrição da personagem.

O capítulo V, "O agregado", identifica José Dias, explicando-lhe a origem.

O capítulo VI, “Tio Cosme”, e o VII, "Dona Glória”, apresentam e identificam o tio e a mãe de Bentinho. Com eles, o desenvolvimento dos acontecimentos da história continua suspenso.

O estranho começa a se desenhar no capítulo VIII, "É tempo". Nele, o narrador ameaça retomar a narração, tal como se pode ver:

Mas é tempo de tornar àquela tarde de novembro, uma tarde clara e fresca, sossegada como a nossa casa e o trecho da rua em que morávamos. Verdadeiramente foi o princípio da minha vida; tudo o que sucedera antes foi como o pintar e vestir das pessoas que tinham de entrar em cena, o acender das luzes, $o$ preparo das rabecas, a sinfonia... Agora é que eu ia começar a minha ópera. "A vida é uma ópera", dizia-me um velho tenor italiano que aqui viveu e morreu... E explicou-me um dia a definição, em tal maneira que me fez crer nela. Talvez valha a pena dá-la; é só um capítulo (1992, p. 817).

Aí se têm coisas muito interessantes: veja-se que o narrador secciona o tempo, desprezando, de certa forma, tudo que acontecera antes daquela tarde de novembro, para reconhecer que, verdadeiramente, ali estava o princípio de sua vida. A infância, portanto, fora algo que apenas preparara o cenário para o que viria depois, na adolescência, o que está bem de acordo com aquela proposta de "atar as duas pontas da vida, e restaurar na velhice a adolescência”. Aparentemente, o narrador faz uma promessa que não se cumpre, pois havia dito que era "tempo de tornar àquela tarde de novembro", o que, de fato, não acontece, posto que a história não continua nem neste capítulo nem no seguinte, que é o capítulo IX.

Mas, como havia alertado, é bom não nos deixarmos envolver pelas artimanhas do narrador; basta refletir um pouco para se concluir que, realmente, a narração é retomada, mas de uma forma inesperada, pois o que ele, de fato, faz é contar a história, só que operando uma síntese drástica. Assim, pode-se dizer que os acontecimentos estão todos concentrados no capítulo IX, onde, em poucas páginas, de forma resumida, ele conta a sua ópera.

Tal capítulo efetiva duas instâncias essenciais de Dom Casmurro: uma espécie de síntese dos acontecimentos e uma narrativa paralela que lança 
luz sobre a trama. Chamo a atenção para o fato de que, nesse capítulo, entram em cena dois narradores: um velho tenor desempregado, Marcolini, e o próprio Bentinho, porém com a particularidade de que Bentinho usurpa a fala de Marcolini, pode ser que numa estratégia para convencer o leitor quanto à veracidade de sua história. Isso, no entanto, pode também ser visto numa outra perspectiva, a do autor-modelo, e, aí, a leitura é diferente. Artimanhas do bruxo Machado, dizendo por vias transversas o que um leitor especial poderia captar. E é nesse plano que se coloca a figura grandiosa de Capitu.

Essas deduções estão respaldadas no próprio capítulo em questão. Senão, vejamos: "Agora é que eu ia começar a minha ópera", é o que diz o narrador. Essa afirmação significativa faz-se seguir de outra não menos importante: "A vida é uma ópera". Ora, o que temos aí? Pode-se dizer que: 1) começava, ali, a narração da vida de Bentinho (isto é, a sua ópera); 2) começava ali a narração do livro (lembre-se que "opera", no latim, é "obra"); portanto, ali tinha início o Dom Casmurro. É de se notar, ainda, uma outra afirmação instigante: a de que a definição de que "a vida é uma ópera", dada por um tenor italiano, era tão convincente que fez o narrador acreditar nela.

Vamos, então, ao capítulo.

\subsection{A vida é uma ópera: os atores}

É importante que retenhamos a informação dada pelo narrador de que a "vida é uma ópera" e de que tal vida (e a sua "definição") é dada em "só um capítulo". É isso que me permite dizer que se a opera é a obra, devo concluir que a vida (de Bentinho) e a obra (Dom Casmurro) estão sintetizadas nesse capítulo IX.

Surge, então, a figura do tenor italiano, Marcolini, que vai dar a definição prometida. E ele o faz, de modo significativo:

- A vida é uma ópera e uma grande ópera. O tenor e o barítono lutam pelo soprano, em presença do baixo e dos comprimários, quando não são o soprano e o contralto que lutam pelo tenor, em presença do mesmo baixo e dos mesmos comprimários. Há coros numerosos, muitos bailados, e a orquestração é excelente... (1992, p. 817).

É dessa forma que o tenor Marcolini abre a explicação de que "a vida é uma ópera”. A história, propriamente dita, virá logo em seguida, mas o 
pequeno trecho traz algumas afirmações muito importantes, ao dizer que se trava uma luta entre o tenor e o barítono pelo soprano, e outra, entre o soprano e o contralto pelo tenor, tudo em presença do baixo e dos comprimários. A estranheza dessas afirmações é que me faz debruçar sobre elas. Aí, então, observo o que representam tais figuras na ópera:

a) tenor - a mais aguda das vozes masculinas. É a voz mais alta;

b) barítono - tom de voz masculina de registro médio, entre o tenor e o baixo;

c) baixo - a mais grave das vozes masculinas;

d) soprano - a voz feminina mais aguda;

e) contralto - a voz feminina mais grave, entre o tenor e o meio-soprano;

f) comprimário - cantor ou dançarino que, na ópera, não faz papel de destaque, mas secundário.

É nesse passo que me dou conta de que as coincidências dessas figuras com personagens de Dom Casmurro são muito encaixadas para serem fortuitas. Assim, não posso deixar de considerar que o tenor, a voz mais aguda da ópera (e aqui volto a lembrar que ópera é a vida [de Bentinho] e, simultaneamente, a obra que se está escrevendo), emblema a figura masculina mais destacada pelo narrador que é Escobar. Por outro lado, o barítono, com sua voz de registro médio, coloca-se entre a importância do tenor e a gravidade do baixo. Ouso dizer que aí temos nada menos que dois bentinhos. Um, representado pelo tenor, é a personagem, sujeito do enunciado, e o outro, caracterizado pelo baixo, é o narrador. Lembre-se que o baixo é a voz masculina mais grave, aquela que tem uma função precisa, ou seja, caracteriza-se o baixo como a voz que se faz notar num conjunto de vozes simultâneas que se desenvolvem independentemente dentro da mesma tonalidade. Essa função contrapontística sugere a presença organizadora do narrador, aquele que faz ressoar sua voz em meio à das personagens.

Para esclarecer essa indicação de se ver Bentinho como personagem - o barítono -, e o narrador - o baixo -, evocaria as considerações que Todorov faz a propósito das "visões da narrativa". Para o autor,

O personagem-narrador não é, pois, uma personagem como as outras; (...) No momento em que o sujeito da enunciação se torna sujeito do enunciado, não é mais o mesmo sujeito que enuncia. Falar de si próprio significa não ser mais "si próprio". O narrador é inominável: se quisermos dar-lhe um nome, ele nos 
permite o nome, mas não se encontra por detrás dele: refugia-se eternamente no anonimato. O narrador do livro é tão fugidiço quanto não importa que sujeito da enunciação, o qual, por definição, não pode ser representado. Em "ele corre", há "ele", sujeito do enunciado, e "eu" sujeito da enunciação. Em "eu corro", um sujeito da enunciação enunciada se intercala entre os dois, tomando a cada um uma parte de seu conteúdo precedente, mas sem fazê-los desaparecer inteiramente: não faz mais que imergi-los. Pois o "ele" e o "eu" existem sempre: o "eu" que corre não é o mesmo que enuncia. "Eu" não reduz dois a um, mas de dois faz três (1970, p. 47).

Dentro dessa linha de raciocínio, não me parece difícil caracterizar Capitu como o soprano (afinal, quem senão ela poderia ser vista como a voz feminina mais aguda), e Sancha, a mulher de Escobar, como o contralto, a voz feminina que se coloca entre o tenor e o meio soprano. Se considerarmos que tenor e barítono lutam pelo soprano, e que soprano e contralto lutam pelo tenor, veremos como aí vão emergir as figuras de Escobar, Bentinho, Capitu e Sancha. E, para completar, vai-se ver que tal disputa se dá ante o baixo e os comprimários. O baixo, como disse, caracteriza o narrador, e os comprimários são revelados nas figuras de segundo plano que assistem a tudo: José Dias, Dona Glória, tio Cosme e prima Justina ${ }^{6}$.

Algo mais pode ser acrescentado às considerações feitas para mostrar a importância das personagens. Veja-se que as figuras de proa na questão do adultério aparecem duas vezes, contra apenas uma aparição dos que nada teriam a ver com o fato. Assim, "o tenor e o barítono lutam pelo soprano (...) quando não são o soprano e o contralto que lutam pelo tenor".

Desse modo, na figuração idealizada pelo tenor Marcolini, está desenhado o quadro essencial da narrativa de Dom Casmurro.

\subsection{A história da criação: os autores e os leitores}

Depois de constatar as correlações estabelecidas acima, o leitor vai de encontro a outra surpreendente dimensão do capítulo IX. Tudo começa com uma revelação do narrador: "E, depois de beber um gole de licor, pousou o cálix, e expôs-me a história da criação, com palavras que vou resumir”.

\footnotetext{
${ }^{6}$ Lembre-se de que há capítulos específicos para todos esses comprimários: capítulos IV e V para José Dias; capítulo VI para tio Cosme; capítulo VII para Dona Glória e capítulo XXI para prima Justina.
} 
Tem-se, aí, um aspecto curioso da narração. O narrador Bentinho vai reproduzir uma história que lhe foi contada por um outro narrador, ou seja, ele se propõe a resumir aquilo que ouvira. Essa superposição de narradores não pode passar despercebida, como se verá mais adiante, e se o leitor observar atentamente a passagem, verá que nela se fazem presentes alguns significantes que chamam a atenção, uma vez que se fala em "história da criação, com palavras que vou resumir". Ora, o narrador promete resumir, ou seja, apresentar sinteticamente, em um só capítulo, conforme se falou antes, a história da criação. É lícito, diante do que já se viu, supor que se trata da história da criação, mas não da criação genesíaca, mas de uma criação com palavras. isto é, da própria narrativa de Dom Casmurro.

E aí vem a história, contada por Marcolini, em que Deus compõe um libreto de ópera que foi apropriado por Satanás e levado para o inferno onde compõe uma partitura aplicada ao texto divino. Entretanto, por mais que insistisse, Satanás não conseguiu convencer Deus a ouvir sua composição; o máximo que obtém é a licença para que a ópera resultante da parceria fosse executada fora do céu, num teatro especial, que é este planeta. É aí, então, que se percebe o descompasso entre o texto de Deus e a música de Satanás, uma vez que "há lugares em que o verso vai para a direita e a música para a esquerda".

Nesse ponto, o leitor, mais uma vez, é tomado de surpresa diante do estranhamento que o texto lhe provoca. Afinal, o que essa parte do capítulo IX tem a ver com a parte inicial, em que Marcolini se refere aos integrantes do corpo de representação da ópera? E, mais uma vez, é preciso dizer que o narrador parece estar brincando com o leitor, propondo-lhe algo desconectado com a narrativa, uma espécie de peça inarticulada e inapropriada para a história que se vai compondo. Basta, entretanto, um exame minucioso para se perceber que a organização do texto obedece a princípios rigorosos de composição.

Recorde-se que Deus, no texto de Marcolini, é identificado ao poeta, o que escreve o libreto, enfim, um manuscrito que não queria pôr em circulação, enquanto Satanás é o maestro, aquele que compõe a música, a partitura que completaria a realização da ópera. Como disse, há um descompasso entre as duas composições, tal como se pode ver na passagem abaixo que serve também para mostrar a articulação entre a parte inicial e esta outra de que estou tratando. 
Com efeito, há lugares em que o verso vai para a direita e a música para a esquerda. Não falta quem diga que nisso mesmo está a beleza da composição, fugindo à monotonia, e assim explicam o terceto do Éden, a ária de Abel, os coros da guilhotina e da escravidão. Não é raro que os mesmo lances se reproduzam, sem razão suficiente. Certos motivos cansam à força de repetição. Também há obscuridades, o maestro abusa das massas corais, encobrindo muita vez o sentido por um modo confuso. As partes orquestrais são aliás tratadas com grande perícia. Tal é a opinião dos imparciais (1992, p. 818).

Como se poderá observar, há, no trecho, alusões por demais significativas para também serem fortuitas. Assim, que indicativo mais adequado haveria para explicar o terceto do Éden senão a representação do trio Escobar, Bentinho e Capitu. Lembre-se que, nesse terceto, faz-se presente, de forma lapidar, a semântica da traição, da tentação e da queda. Quanto à "ária de Abel", leve-se em consideração que a ária é uma peça de música para uma só voz. Ora, a "uma só voz" da narrativa é a de Bentinho, na sua dimensão de narrador, aquele Abel traído e morto pelo irmão, no caso, Escobar. E os "coros da guilhotina" emblemam bem as mortes perpetradas e acontecidas, de Capitu e de Ezequiel, além dos "coros da escravidão", marcados na idéia de submissão que é bem ilustrada pelo próprio Bentinho, escravo de uma idéia fixa, a da sua submissão ao fantasma do adultério.

Observe-se que, a respaldar tais articulações, explicita-se a passagem: "Não é raro que os mesmos lances se reproduzam, sem razão suficiente. Certos motivos cansam à força da repetição", que é bastante significativa para dar a ver a repetição de uma idéia fixa, a do adultério. Mas é importante ter em mente o modo como o narrador procura justificar a traição de que teria sido vítima, apelando para a lógica da repetição, como se estivesse a dizer que ela é resultado da própria condição humana, daí que lances como o do adultério possam se reproduzir "sem razão suficiente" e que tais "motivos cansam à força da repetição".

Neste momento, já se pode indicar um outro princípio norteador da leitura do texto. Quero me referir ao fato de que se vislumbram, no capítulo IX, dois movimentos estruturais. Um, representado pelo texto do poeta, ou seja, o libreto que Deus escreveu. Tem-se, aí, o mecanismo da produção do texto: Deus-poeta, produzindo o poema-libreto da ópera. O outro, representado pela música do maestro, ou seja, pela partitura 
que Satanás produziu, caracteriza-se como um outro mecanismo, o da recepção do texto: Satanás-maestro, aplicando ao texto do poeta a melodia com que o lê. Curiosamente, dá-se aí um movimento intercambiante entre o poeta e o maestro, no que diz respeito à produção e à recepção dos textos. Inicialmente, Deus produz o texto do libreto que é lido/recebido com entusiasmo por Satanás. Depois, Satanás produz o texto melódico que será lido/recebido com desdém por Deus. Produção e recepção, ou seja, escritura e leitura seriam, pois, os dois movimentos que circulam na relação Deus-poeta/Satanás-maestro.

Atento a essa formulação, quero destacar o trecho: "Também há obscuridades, o maestro abusa das massas corais, encobrindo muita vez o sentido por um modo confuso. As partes orquestrais são aliás tratadas com grande perícia. Tal é a opinião dos imparciais". Veja-se como há, aí, alguns índices bastante significativos, que apontam para dois níveis no movimento da leitura. Um desses níveis responde por uma leitura centrada no texto enquanto produto de um fundamentalismo cultural que se propõe como um centro inquestionável. Tal leitura defende a pureza do texto do poeta. Num outro nível, encontra-se uma leitura que lida com as incertezas, descentrada, portanto, e é aquela que valoriza a intervenção do maestro. Ela é que fala das obscuridades e é justamente isso que produz o grande efeito da leitura de Dom Casmurro, uma vez que é essa obscuridade, ou melhor, esse enigma que transita pela narrativa, que conduz o leitor às várias ilações que o texto propicia. Não há dúvida de que a questão fulcral, a ocorrência ou não do adultério de Capitu, é o principal agente do enigma e causa das mais acirradas discussões dos leitores. É assim que se pode entender a afirmação de que "o maestro abusa das massas corais, encobrindo muita vez o sentido por um modo confuso". Há, nesse aspecto, uma postura que começa com o autor, passa pelo autor-modelo, até chegar ao narrador, num processo enunciativo que parece ter, claramente, a determinação de levar o leitor a diferentes deduções sem que qualquer delas se explicite como indiscutível e definitiva ${ }^{7}$. Essas "massas corais" resultam, pois, de uma estratégia narrativa

\footnotetext{
${ }^{7}$ Refiro-me aqui à caracterização de autor-modelo expressa por Umberto Eco (1994). Não se pode deixar de lado a idéia de que Machado de Assis, o "bruxo do Cosme Velho", sempre estabeleceu um jogo com o leitor em que se patenteia a idéia de oferecer e negar pistas. É nessa perspectiva que se pode ver a importância das instâncias do autor-modelo e do narrador como mecanismos intermediários valiosos na relação entre o autor-sujeito da escritura e o destinatário-leitor.
} 
que parece ter a nítida intenção de encobrir o sentido, acentuando o enigma como linha de força do romance ${ }^{8}$.

Não posso deixar ainda de mencionar a pequena mas significativa frase: “Tal é a opinião dos imparciais". Essa opinião é a que fala do enigma e da impossibilidade de oferecer uma interpretação definitiva para o que ele propõe. Os "imparciais", então, caracterizam-se como aqueles leitores que se abstêm de julgar Capitu e de fechar a questão relativa a uma leitura conclusiva do romance.

Percebe-se, neste passo, que os dois níveis de leitura são concebidos por duas espécies de leitores: os amigos do maestro e os amigos do poeta. Vejase quão significativa é a passagem abaixo:

Os amigos do maestro querem que dificilmente se possa achar obra tão bem acabada. Um ou outro admite certas rudezas e tais ou quais lacunas, mas com o andar da ópera é provável que estas sejam preenchidas ou explicadas, e aquelas desapareçam inteiramente, não se negando o maestro a emendar a obra onde achar que não responde de todo ao pensamento sublime do poeta (1992, p. 818).

Têm-se, aí, pois, os amigos do maestro, aqueles que vêem o romance como obra-prima, embora um ou outro admita "certas rudezas e tais ou quais lacunas". Entretanto, diz o narrador que, "com o andar da ópera" é provável que as lacunas sejam preenchidas ou explicadas e as rudezas desapareçam inteiramente. A passagem me impõe algumas reflexões. Como se sabe, Capitu é um exemplo perfeito da figura feminina que Machado de Assis esculpiu e sua inserção na realidade das relações sociais e dos procedimentos ético-morais do século XIX chega a ser surpreendente, uma inadequação que, aliás, está muito bem explicitada no levantamento que Ingrid Stein fez no seu Figuras femininas em Machado de Assis (1984). Assim, é de se notar que alguns tipos machadianos de mulher avançaram um século de seu tempo, causando espécie até mesmo em leitores do século XX e Capitu é, sem dúvida, o mais significativo. Assim, num retrospecto rápido, pode-se ver que as opiniões sobre a existência ou não do adultério mostraram-se, até há algum tempo, da seguinte forma: o adultério, realmente,

${ }^{8}$ Lembro, nesse aspecto, o ensaio “Dom Casmurro começou na imprensa com José Dias", de Letícia Malard, citado na nota 2, ao qual remeto o leitor interessado na questão. 
ocorrera e Capitu era, sistematicamente, condenada pelo desvio 9 . Nos dias contemporâneos, com todas as mudanças de costumes e uma nova dinâmica social, muitos procedimentos tidos como inaceitáveis socialmente são vistos como preconceitos de uma época que passou e, nesse cenário, Capitu vem sendo considerada de outra forma. Ou se se disser de outro modo, Capitu, nos dias atuais, já não é mais julgada. Quer dizer, hoje, existe um outro patamar de leitura de Dom Casmurro, resultado do "andar da ópera" que acaba explicando as lacunas e fazendo desaparecer as rudezas, aquilo que era inaceitável. E, para não fugir à proverbial ironia machadiana, o maestro não se nega "a emendar a obra onde achar que não responde de todo ao pensamento sublime do poeta”. De fato, essa satânica linha de leitura não corresponde àquela sublime leitura dos que defendem o texto do poeta.

Por outro lado, os amigos do poeta "juram que o libreto foi sacrificado, que a partitura corrompeu o sentido da letra”, sendo até "contrária ao drama”. Ora, esses dois níveis do movimento da leitura indicam muito claramente duas qualidades de leitores. Os que se aferram à produção do texto, tomando-o como verdade implacável, acreditando no que ele diz, sem desconfiar de intenções e de estratégias da enunciação e, de outro lado, os que lêem buscando sempre o sentido mascarado, o deslizamento dos significantes, a indeterminação dos significados.

Esse tipo de leitor - os amigos do poeta -, sempre achará, por exemplo, que o grotesco (a obsedante certeza de Bentinho, por exemplo), nunca está no texto. São eles que, no caso de Dom Casmurro, acreditam piamente que Capitu é uma adúltera que levou ao desespero o pobre Bentinho. Não quero ser irônico e muito menos desrespeitoso, mas não tenho como deixar de classificar Otto Lara Resende, Sepúlveda Pertence, Fernando Sabino e Carlos Heitor Cony como leitores que compõem uma refinada e ilustre galeria de amigos do poeta.

Um outro aspecto que me chama a atenção é a referência à comédia de Shakespeare, Mulheres patuscas de Windsor, vista pelos amigos do poeta como o texto que a ópera de Satanás quis imitar. Está evidenciada, aí, a ironia machadiana. A acusação de plágio que se imputa a Satanás - uma imitação desqualificativa, porque imita uma obra patusca -, é respondida com

\footnotetext{
${ }^{9}$ Nesse ponto quero lembrar que sempre foi comum fazer o julgamento de Capitu em júris simulados, como uma prática de tornar mais atraente a leitura do livro a estudantes de diversos níveis.
} 
a própria acusação, ou seja, à época da composição da ópera, nem a farsa nem o poeta inglês eram nascidos. Assim, Shakespeare não passa de um plagiário. Ora, o que subjaz nesta passagem é a reafirmação de que a ópera que se representa tem lugar num teatro especial que é este planeta, contando "com uma companhia inteira, com todas as partes, primárias e comprimárias, coros e bailarinos". Quer dizer, Shakespeare apenas imitou o que já existia: o mundo onde se desenrola a vida humana com suas virtudes, seus vícios, seus contrastes e seus paradoxos. Essa conclusão recoloca a situação de Capitu no centro mesmo das leituras contemporâneas que insistem na posição de que não é possível condená-la à vista de a narrativa sonegar qualquer indicação objetiva a esse respeito, procurando, ao contrário, privilegiar o mistério e o enigma que circundam a relação de Bentinho e Capitu. Afinal, mistério e enigma são componentes que circulam a própria vida humana, na sua permanente busca de explicação para a dúvida existencial da origem do ser. Daí se poder dizer que a condenação de Capitu não passa de um juízo preconceituoso, uma vez que ela, como qualquer outra mulher, apenas ocupa um lugar na representação do teatro da vida.

E é por isso mesmo que a narrativa diz: “- Esta peça, concluiu o velho tenor, durará enquanto durar o teatro, não se podendo calcular em que tempo será ele demolido por utilidade astronômica. O êxito é crescente" (1992, p. 819).

Desse modo, o que Machado de Assis coloca com sua obra é a projeção de uma mulher que, vivendo sob o rigor preconceituoso da sociedade do século XIX, antecipou-se ao seu tempo para revelar-se uma mulher contemporânea. E isso é detectável a partir do conflito que se estabelece entre os leitores do poeta e do maestro. Aqueles estão vetorizados para o passado, emblemas autênticos de uma leitura restrita às aparências, e estes para o aqui e agora do seu tempo, prodigalizando uma leitura que transita pelos diversos escaninhos do texto.

Um outro detalhe que pode passar despercebido é o que se insinua no final da fala de Marcolini: "Poeta e músico recebem pontualmente os seus direitos autorais, que não são os mesmos, porque a regra da divisão é aquilo da Escritura: 'Muitos são os chamados, poucos os escolhidos'. Deus recebe em ouro, Satanás em papel” (1992, p. 819).

Lembre-se que o texto machadiano lida com duas díades: Deus / Satanás e Poeta / Maestro. Como já disse anteriormente, o significante Deus aponta a autoria do texto do libreto, enquanto o significante Satanás direciona-se 
para a autoria da música que se aplica ao libreto, ou seja, ambos contemplam nesta instância o mecanismo da produção. De outro lado, como já destaquei, os significantes poeta e maestro estão ligados ao movimento da leitura, ou seja, à recepção. Sobre os dois níveis da recepção já falei. Resta agora refletir sobre a questão da autoria e isso me parece significativamente ligado à questão do "ouro" e do "papel", significantes indicadores dos direitos autorais. Se se tem em vista que a narrativa fala que Deus escrevera "um libreto de ópera, do qual abrira mão, por entender que tal gênero era impróprio da sua eternidade", vai-se perceber que tal texto está marcado pelos sinais que indicam a repressão em nome da virtude, da grandiosidade, posto que ele não estava à altura da eternidade divina. É um texto, pois, que denota a existência de restrições que se impõem aos procedimentos que não se submetem a uma lei, a uma autoridade, a um código. Daí podermos aproximá-lo do significante "ouro" que relaciona significados como "raridade", "preciosidade".

Considerando-se a outra produção, a música de Satanás, vai-se perceber que ela anda em dissonância com o texto de Deus: "Com efeito, há lugares em que o verso vai para a direita e a música para a esquerda”. Em outras vezes, a música está mesmo em rota de colisão com a criação divina, pois chega a ser "absolutamente diversa e até contrária ao drama”. Assim, impõe-se a dedução de que a produção de Satanás desenvolve-se num plano de maior liberalidade, apontando as contradições e os contrastes que envolvem o ser, relativizando o princípio da autoridade, a obediência irrestrita a uma lei, a um código. E é exatamente essa acomodação ao gênero humano, com todas as suas caracterizações, que aproxima o trabalho de Satanás do significante "papel” e sua gama de significações em que se destaca a idéia de "profusão", de "existência abundante", de "leveza". Ora, fica, de certo modo, evidente que o texto de Deus lida com o absoluto, com a raridade, com a rigidez de um centro marcado pelo princípio da limitação numérica, enquanto a obra de Satanás trabalha a idéia do relativo, da falta de cerimônia, da flexibilidade, do desprendimento. Daí Deus receber a pureza rara, em parcas quantidades, com o ouro de uns poucos e Satanás ser agraciado com as multidões do papel. Numa última palavra, pode-se dizer que Bentinho declama os versos do poeta e Capitu dança a música do maestro, daí a leitura dos amigos do poeta entrar em rota de colisão com a dos amigos do maestro.

Veja-se, agora, o final do texto: 
- Tem graça...

- Graça? Bradou ele com fúria; mas aquietou-se logo, e replicou: - Caro Santiago, eu não tenho graça, eu tenho horror à graça. Isto que digo é a verdade pura e última. Um dia, quando todos os livros forem queimados por inúteis, há de haver alguém, pode ser que tenor, e talvez italiano, que ensine esta verdade aos homens. Tudo é música, meu amigo. No princípio era o dó, e o dó fez-se ré etc. Este cálix (e enchia-o novamente), este cálix é um breve estribilho. Não se ouve? Também não se ouve o pau nem a pedra, mas tudo cabe na mesma ópera... (1992, p. 819).

O fechamento do capítulo retoma, de forma sintética, todo o entendimento explicitado até então. Mais uma vez, contrapõem-se os textos de Deus e de Satanás. O primeiro está marcado por alguns significantes bem característicos. Note-se, por exemplo, como Marcolini toma o significante "graça", expresso por Bentinho, na conhecida significação de "dito ou ato espirituoso ou engraçado", para ressemantizá-lo numa perspectiva teológica, com o objetivo de negar o texto de Deus ${ }^{10}$. Também no significante "livro" pode-se ver outra manifestação desse texto - atente-se para a aproximação libreto/livro - e seu aproveitamento para outra negação: a de que chegará o dia em que todos os livros serão queimados por inúteis. Desse modo, percebe-se como Marcolini vai profetizando o desenrolar dos tempos, a avassaladora marcha da humanidade na direção do prazer, do gozo, da liberalidade nos procedimentos sociais, o que se atesta com a conviç̧ão expressa de que o texto do Deus-poeta chegará ao desaparecimento dada a inexistência de condições para que ele sobreviva. É nesse momento que surgirá alguém "pode ser que tenor, e talvez italiano, que ensine esta verdade aos homens. Tudo é música, meu amigo". Caracteriza-se, assim, a exponencial predominância da obra de Satanás, da música do maestro onde caberá, com muita graça, a figura de Capitu.

E para que a substituição se consume, atente-se para o resto da fala de Marcolini, em que se destaca a afirmação de que "Tudo é música, meu amigo. No princípio era o dó, e o dó fez-se ré etc.” Aí, percebe-se que o texto dubla o "Prólogo" do Evangelho segundo S. João, no versículo 1 - "No princípio

\footnotetext{
${ }^{10}$ No Aurélio, destacam-se como significados de "graça", nessa perspectiva teológica: Dom ou virtude especial concedido por Deus como meio de salvação ou santificação; favor ou mercê concedida por Deus a uma pessoa; milagre.
} 
era o verbo, e o verbo estava com Deus..." - e no versículo 14 - "E o verbo se fez carne, e habitou entre nós.... Tem-se, pois, a substituição do verbo (que se liga aos significantes palavra, libreto, livro), pela música.

Também a referência ao cálice é outra forma de projetar a substituição do texto do Deus-poeta pela partitura de Satanás-maestro. Ao dizer que "este cálix é um breve estribilho", tem-se, novamente, a redução das escrituras à dominação da música, uma vez que a idéia de cálice remete aos evangelhos de S. Mateus (26, 27-28), S. Marcos (14, 23-24), S. Lucas $(22,20)$ e à Primeira Epístola de S. Paulo aos Coríntios $(11,25)^{11}$. Em todos esses textos sagrados, acentua-se a fala de Cristo aos apóstolos, na cerimônia em que Jesus, tomando o cálice, celebra o testamento de seu sangue que será derramado pelos homens. Na interpretação descentrada que o narrador Marcolini empresta ao simbolismo do cálice, predomina a irreverência com que se acentua a supremacia da música e, por essa via, à afirmação da desobediência aos princípios consagrados, à lei, ao código. É nesse universo descentrado que a narrativa parece inserir a figura de Capitu com toda sua força de rompimento e de rebeldia. Enfim, pode-se dizer que a personagem machadiana decola dos rigorosos limites de seu tempo para anunciar, como um arauto sedutor, a mulher que transita num outro mundo que se articulou cem anos depois.

\subsection{A aceitação da teoria: o duo, o trio, o quatuor}

Desse modo, ao final do capítulo IX, o leitor presume que, finalmente, a história que se interrompera no capítulo III será retomada. Ledo engano. Depois de gastar sete capítulos com o "pintar e vestir das pessoas que tinham de entrar em cena” - as referências a si próprio, ao Bentinho personagem e a Capitu, assim como a apresentação detalhada dos comprimários (José Dias, Tio Cosme e D. Glória) - o baixo opera “o acender das luzes,

\footnotetext{
${ }^{11}$ a) Evangelho de S. Mateus: 26, 27-28: E tomando o cálice, deu graças: e deu-lho, dizendo: Bebei dele todos (27). Porque este é o meu sangue do novo testamento, que será derramado por muitos para remissão de pecados (28).

b) Evangelho de S. Marcos: 14, 023-24: E tendo tomado o cálice, depois que deu graças, lho deu: e todos beberam dele (23). E Jesus lhes disse: Este é o meu sangue do Novo Testamento, que será derramado por muitos (24).

c) Evangelho de S. Lucas: 22, 20: Tomou também da mesma sorte o cálice, depois de cear, dizendo: Este cálice é o Novo Testamento em meu sangue, que será derramado por vós.

d) Primeira Epístola de S. Paulo aos Coríntios: 11, 25: Por semelhante modo, depois de haver ceado, tomou também o cálice, dizendo: Este cálice é o novo testamento do meu sangue: fazei isto em memória de mim, todas as vezes que o beberdes.
} 
o preparo das rabecas, a sinfonia", anunciando, desse modo, a sua ópera. Vêm, então, os participantes de primeiro plano e, logo a seguir, a encenação propriamente dita, explicitada na história da criação em palavras que ele resumiu.

Isso feito, o narrador ainda acrescenta um outro capítulo, o décimo, intitulado "Aceito a teoria", o qual, dada a sua importância na confirmação do que havia sido dito no capítulo anterior, vale a pena transcrever:

Que é demasiada metafísica para um só tenor, não há dúvida; mas a perda da voz explica tudo, e há filósofos que são, em resumo, tenores desempregados.

Eu, leitor amigo, aceito a teoria do meu velho Marcolini, não só pela verossimilhança, que é muita vez toda a verdade, mas porque a minha vida se casa bem à definição. Cantei um duo terníssimo, depois um trio, depois um quatuor... Mas não adiantemos; vamos à primeira parte, em que eu vim a saber que já cantava, porque a denúncia de José Dias, meu caro leitor, foi dada principalmente a mim. A mim é que ele me denunciou (1992, p. 819).

Esse capítulo é importante porque permite que se flagrem algumas artimanhas do narrador. É bom lembrar, então, que o narrador do capítulo IX é, na sua essência, o tenor Marcolini. É ele quem apresenta os participantes da ópera - tenor, barítono, soprano, contralto, baixo e comprimários - e quem conta a história da criação. Mas não se pode esquecer que essa narração foi, a bem dizer, apropriada pelo narrador Bentinho, pois este é quem, de fato, conta a história, fazendo-o "com palavras que vou resumir".

É de se notar ainda que, logo no início, o narrador Bentinho já apresenta a justificativa para não dar a voz a Marcolini, e isso é feito na singeleza da frase que abre o capítulo: "Já não tinha voz, mas teimava em dizer que a tinha”. Quer dizer, tem-se aí uma narração de um narrador, controlada pela voz de um outro. Diante da ingerência daquele que se poderia chamar de "narrador oficial", o leitor fica inquieto ante o que está sendo dito, desconfiado da veracidade da narração. Mas há traços no texto que podem ser levados à conta da presença de uma outra voz, ou, talvez fosse melhor dizer, de um vagido que, ao cabo, seria a palavra daquele que Umberto Eco chama de autor-modelo.

Abro, então, um parêntese para refletir sobre isso. Como se sabe, a tão decantada "morte do autor" nada mais é que um processo simples de substituição. Basta raciocinar por analogia com a instância mesma da linguagem, mais precisamente com a funcionalidade do signo lingüístico. $\mathrm{O}$ signo 
é, pura e simplesmente, o resultado de uma substituição. É isso que se encontra na concepção de Derrida, tal como explicada por Silviano Santiago:

Quando não podemos tomar ou mostrar a coisa, passamos pelo desvio do signo [...]. A circulação dos signos difere o momento em que poderíamos encontrar a própria coisa[...]. O signo diferindo a presença, só é pensável a partir da presença que ele difere e em vista da presença diferida que se quer reapropriar (1976, p. 85).

Dentro desse princípio, tem-se que o narrador é uma instância discursiva, criada pelo autor, pelo fato mesmo de que este não pode "tomar ou mostrar a coisa", ou seja, a história que ele vai contar. Tem-se, então, que o autor, devido a essa indesviável impossibilidade, acaba substituído ao passar pelo "desvio do narrador". E se é substituído, na verdade, ele desaparece, morre, da mesma forma que a coisa morre ao ser substituída pelo signo.

Esse desaparecimento do autor, entretanto, não é um ponto vencido. Talvez se pudesse dizer que o autor desaparece, mas não se conforma com isso, razão por que, vez por outra, ei-lo a meter o bedelho na narração, e, à impossibilidade de dizer, sussurra, murmura alguma coisa, solta, enfim, seus vagidos. E, para isso, ele se vale de uma "voz fantasmática", grunhida por uma espécie de "alma de outro mundo" que, na formulação elegante de Umberto Eco, recebe o nome de autor-modelo.

O professor italiano indica que "o autor-modelo é uma voz que nos fala afetuosamente (ou imperiosamente, ou dissimuladamente), que nos quer a seu lado. Essa voz se manifesta como uma estratégia narrativa, um conjunto de instruções que nos são dadas passo a passo e que devemos seguir quando decidimos agir como leitor-modelo" (1994, p. 21). Vê-se, pois, que o autor-modelo é, na verdade, uma estratégia que se utiliza na narrativa com o objetivo de orientar o trabalho do leitor. Não se trata, como adverte Eco, de uma "voz gloriosa "ou de uma "estratégia sublime", mas apenas de um componente importante para estimular a reflexão do leitor, levando-o a um trabalho de leitura que se deve pautar, sobretudo, pela atenção detalhista com que o texto deve ser percorrido. Na verdade, há coisas numa narrativa que passam despercebidas justamente porque não se leu com olhos errantes, que passeiam sobre a página, vendo interesse até naquilo que, à primeira vista, parece simples ou óbvio demais. 
Um bom exemplo dessa presença do autor-modelo, na obra machadiana, pode ser extraído do já citado ensaio de Marta de Senna, em que a autora procura mostrar como a narração em Dom Casmurro revela a presença de um narrador embusteiro, permanentemente voltado para apanhar o leitor no contrapé. Dentre as estratégias utilizadas, podem-se contar alguns elementos que são importantes para a compreensão de aspectos surpreendentes da leitura. É o caso do comentário que Senna faz acerca dos medalhões de imperadores que Bentinho mandou pintar nas paredes da sala da casa que ele construiu no Engenho Novo, com a preocupação de reproduzir a antiga residência de Mata-cavalos, onde passara sua infância. A ensaísta lembra que, junto das figuras dos imperadores César, Augusto e Nero, aparece um quarto governante, e sua importância é fulcral, conforme se lê na passagem abaixo:

O narrador introduz a figura menos conhecida do rei Massinissa da Numídia. Aliado dos romanos, Massinissa é casado com Sofonisba, cartaginesa irmã de Aníbal, educada para odiar Roma. Compelido pelo vitorioso Cipião a entregar a mulher para ser submetida à vergonha pública em Roma, Massinissa dela se compadece e, para poupá-la do que seria um ultraje bem pior que a morte, manda-lhe uma taça de veneno, que ela toma de bom grado. (...) Mas ao inserir aí essa desconhecida Sofonisba, presenteada pelo marido com uma taça de veneno não por tê-lo traído, mas para não trair os seus princípios, para preservar a sua integridade, não estaria o autor Machado prevenindo-nos contra seu narrador? (...) A acreditarmos em Sofonisba inocente e altiva (como será de altivez a atitude final de Capitu), o autor nos está prevenindo contra o narrador, por cujas estratégias de embuste é, em última instância, o único responsável. (2000, p. 168).

Ora, essa voz que Marta de Senna atribui ao autor Machado (que estaria "prevenindo-nos contra seu narrador), com toda a certeza é a do autormodelo. Creio não importar muito os nomes diferentes que se atribuem ao autor-modelo, uma vez que sua presença é reconhecida na dissimulação das figuras dos imperadores, bem de acordo com as colocações de Umberto Eco que reproduzi acima.

Diante do exposto, parece-me pertinente propor a classificação de Marcolini, o narrador que não tem voz, mas que conta a história da criação (criação do romance com palavras que o narrador Bentinho resumiu), como o autor-modelo que co-labora para despertar a imaginação do leitor. 
E isso é o que suponho ter feito, ao propor a leitura do capítulo IX como uma instância que resume a história e lança luz sobre a situação das personagens centrais, principalmente Capitu.

Mas quero lembrar uma outra colocação que Umberto Eco faz a respeito dos processos narrativos, pois julgo que ela será útil na leitura do capítulo X. Para Eco, há casos em que a presença do autor-modelo é explícita, até mesmo descarada, segundo suas palavras. O mestre italiano, porém, afirma que há "outros casos em que, com maior desfaçatez, porém, mais sutilmente, apresentam-se autor-modelo, autor empírico, narrador e entidades ainda mais vagas, colocadas no texto narrativo com o propósito explícito de confundir o leitor" (1994, p. 24). Ora, esse propósito de confundir o leitor parece a marca mesma da narrativa machadiana, de que Dom Casmurro talvez seja o exemplo mais acabado. Para além da questão de ter ou não acontecido o adultério, há situações correlatas que só fazem infernizar o trabalho do leitor, seja ele de que espécie for.

Vejamos, pois, essa situação da leitura, tal como se pode vislumbrá-la no capítulo X. Como leitores-modelo, já tínhamos colocado no universo de nossa reflexão a advertência que o narrador nos parecia ter feito quanto ao narrador Marcolini: a de que não tinha voz e, ainda assim, insistia em contar uma história. Essa advertência pode levar o leitor a algumas indagações:

- A história da criação, resumida pelo narrador Bentinho, seria digna de fé?

- Tal história não estaria corrompida pela interferência de uma voz que substituía a voz de Marcolini?

- A história da criação, como foi contada, se aplicaria àqueles que representavam o corpo da ópera, ou seja, Bentinho, Escobar, Capitu?

Num primeiro momento, o leitor tenderia a desconfiar da possibilidade, uma vez que o narrador como que estaria interessado em colocar a história da criação em dúvida, ao dizer que aquilo tudo "é demasiada metafísica para um só tenor", o que, inclusive, seria explicado pela perda da voz. Ou seja, à falta do que fazer, como cantor, o tenor é levado a filosofar, a imaginar e, assim, a criar algo supra-real, eis que a metafísica é, na sua essência, uma metà tà physiká, ou seja, aquilo que "está depois dos tratados da física".

Mas se o leitor continua a refletir e, principalmente, a buscar o jogo significante das palavras, verá que a metafísica é considerada, na verdade, 
como princípio que esclarece o próprio real, ou ainda, como conhecimento que explica as causas e os princípios primeiros do ser.

Essas dúvidas, no entanto, parecem desvanecer-se na medida em que o narrador afirma incisivamente: "Eu, leitor amigo, aceito a teoria do meu velho Marcolini”. Notem-se, aí, alguns aspectos que não podem ser negligenciados, a começar pelo fato de que o narrador se dirige ao leitor, como que o chamando para a compreensão do que vai dizer. É nesse momento que vem a afirmação decisiva, que foi até mesmo aproveitada no título do capítulo: "aceito a teoria". Quer dizer, a teoria de Marcolini - enfeixada nos papéis desempenhados pelo tenor, barítono, baixo, contralto e soprano, assim como na história da criação - é confirmada duas vezes pelo narrador. Primeiro, ao dizer que ela tem verossimilhança. Ora, para que não se fique com o indicativo de que o enunciado por Marcolini guarda tão-somente uma aparência de verdade, o narrador, depois de dizer que a verossimilhança "é muita vez toda a verdade", faz questão de afirmar que a sua vida "se casa bem à definição". E, aí, vem a confirmação definitiva do que fizera (ou cantara) na ópera, na vida, na obra: as suas relações com Capitu (duo terníssimo), com Capitu e Escobar (trio) e com Capitu, Escobar e Ezequiel (quatuor). Note-se que, dessas relações, apenas a primeira é adjetivada - duo terníssimo -, sinal evidente de que, depois, o sentimento de afeto da relação desaparece.

É preciso, mais uma vez, chamar a atenção do leitor para as artimanhas do narrador Bentinho. É que, como se pôde confirmar com o capítulo X, ele aceita a teoria, mas a canaliza para os seus objetivos, ou seja, procura ratificar a posição de que tivera um casamento que foi invadido por dois estranhos, Escobar e Ezequiel. A acusação é feita e, imediatamente, o narrador como que procura não dar tempo à reflexão do leitor. É por isso que ele se apressa em dizer: "Mas não adiantemos", convidando o leitor a voltar à primeira parte, aquela da denúncia de José Dias. Quer dizer, ele lança uma tese - a da traição - e, mais que depressa, volta ao passado para começar a detalhar a história com que quer convencer o leitor do que foi anunciado, no "resumo da ópera".

É assim que Capitu é condenada, motivo por que é importante lembrar a presença do autor-modelo, figurado na voz de Marcolini, no capítulo IX, ao falar da ópera e da história da criação em que se destaca a composição do maestro-Satanás. É com essa formulação que o autor empírico insinua a figura da mulher exponencial que foi Capitu, espécie de Joana D’arc em meio ao autoritarismo falocêntrico que vigia no século XIX. A Capitu "ressaca dos 
mares, sereia do sul", no dizer da canção de Luiz Tatit, sobrevive, entretanto, transfigurada numa ópera indestrutível, que é o Dom Casmurro.

\section{Referências Bibliográficas}

ASSIS, J.M. Machado de. Dom Casmurro, in: Obra completa, v. 1, Rio de Janeiro: Editora Nova Aguilar, 1992.

ECO, Umberto. Seis passeios pelos bosques da ficção. São Paulo: Companhia das Letras, 1994.

EHRENZWEIG, Anton. Psicanálise da percepção artística. Uma introdução à teoria da Percepção Inconsciente. Rio de Janeiro: Zahar Editores, 1977.

MALARD, Letícia. "Dom Casmurro começou na imprensa por José Dias”. Scripta, Belo Horizonte, n. 6, p. 123-128, 1. ${ }^{\circ}$ semestre / 2000.

SANTIAGO, Silviano (org). Glossário de Derrida. Rio de Janeiro: Livraria Francisco Alves Editora, 1976.

SABINO, Fernando. Amor de Capitu. Leitura fiel do romance de Machado de Assis sem o narrador Dom Casmurro. 4. ${ }^{a}$ ed., São Paulo: Editora Ática, 2003.

SENNA, Marta de. "Estratégias de embuste: relações intertextuais em Dom Casmurro". Scripta, Belo Horizonte, n. 6, p. 167-176, 1.o semestre / 2000.

STEIN, Ingrid. Figuras femininas em Machado de Assis. Rio de Janeiro: Paz e Terra, 1984.

TODOROV, Tzetan. Estruturalismo e poética. São Paulo: Cultrix, 1970. 